\title{
Economizer water-wall damages initiated by feedwater impurities
}

\author{
Sonja M. Vidojković ${ }^{1}$, Antonije E. Onjia ${ }^{2}$, Aleksandar B. Devečerski ${ }^{3}$, Nebojsa N. Grahovac ${ }^{3}$, \\ Aleksandra B. Nastasović ${ }^{1}$ \\ ${ }^{1}$ University of Belgrade, Institute of Chemistry, Technology and Metallurgy, Belgrade, Serbia \\ ${ }^{2}$ University of Belgrade, Laboratory of Chemical Dynamics and Permanent Education, "Vinča" Institute of Nuclear \\ Sciences, Belgrade, Serbia \\ ${ }^{3}$ University of Belgrade, Laboratory of Material Science, "Vinča" Institute of Nuclear Sciences, Belgrade, Serbia
}

\begin{abstract}
The main causes of efficiency loss in thermal power plants are boiler tube failures that diminish unit reliability and availability, and raise the cost of the electric energy. For that reason, the regular examination of boiler tubes is indispensable measure for prevention of future malfunctions of power units. The microscopic examination of economizer's inner wall microstructure, the analysis of chemical composition of deposit using X-ray diffraction (XRD) and scanning electron microscopy/energy dispersive spectroscopy (SEM/EDS) have been performed in a subcritical power plant. Stress corrosion cracking, pitting corrosion, destroyed protective magnetite layer, presence of magnetite and hematite in deposit and corrosive impurities within the cracks have indicated the effect of inadequate quality of feedwater that cannot entirely ensure reliable operation of the boiler. It may be stated that maintenance of present boiler does not provide its reliable operation. The extensive chemical control of water/steam cycle was recommended.
\end{abstract}

Keywords: boiler tube, deposition, corrosion, feedwater impurities.

PROFESSIONAL PAPER

UDC 621.311:621.643:620.193:54

Hem. Ind. 68 (5) 559-563 (2014)

doi: 10.2298/HEMIND130715082V

Available online at the Journal website: http://www.ache.org.rs/HI/

The failure of boiler tubes is one of the foremost problems in most of processing industries involving thermal power plants [1-6]. It causes considerable efficiency loss and consequently enormous economic effects $[7,8]$. Tubes are typically made of carbon or low alloy steel and exposed to stress, aggressive environment and diverse phases of water at high temperature and pressure. This environment has a high potential of corrosion processes development. Thus, majority of boiler tube failures are reported from waterside corrosion [9-13].

The review of inspection and maintenance records of $210 \mathrm{MW}$ power plant operating at subcritical parameters revealed numerous shutdowns ensued from boiler tube failure. Furthermore, the number of boiler tube failures and breakdowns on power units has been increasing in the last ten years. Economizer, which is one of the critical components of boiler generally, was the most damaged part. In order to provide evidences for economizer's inner wall condition and reveal possible causes of its damages, the metallographic examination of metal surface and deposit structure was undertaken. The boiler is coal-fired with natural circulation of the boiler water. The boiler tubes were made

Correspondence: S.M. Vidojković, University of Belgrade, Institute of Chemistry, Technology and Metallurgy, Njegoševa 12, 11001 Belgrade, P.O.B. 473, Serbia.

E-mails: sonja66yu@yahoo.com; sonjavidojkovic@chem.bg.ac.rs

Paper received: 15 July, 2013

Paper accepted: 29 October, 2013 of steel St.45.8 DIN 17175 and operated $19871 \mathrm{~h}$. All-volatile treatment $(\operatorname{AVT}(\mathrm{R}))$ was employed for feedwater conditioning. This treatment comprises the dosing of ammonia, as alkalizing, and hydrazine, as reducing agent.

\section{EXPERIMENTAL ANALYSIS}

The specimens of the economizer tube were subjected to various laboratory examinations and analysis. These included visual inspection, optical microscopic (metallographic) analysis, X-ray diffraction (XRD) and scanning electron microscopy/energy dispersive spectroscopy (SEM with EDS).

\section{Techniques and instrumentation}

The optical microscopy of internal wall was employed for metallographic examination of tubes. The metallographic examination was carried out along the tube. The examination was made both on the internal surfaces and on cross-sectional surfaces of the tubes. The microstructure analyses were made using light microscope Zeiss Axioplan with diverse enlargements. Specimens were photographed by digital camera. The entire cross-section of the tubes was observed and the thickness of corrosion layer was measured. The measurement was carried out at ten points around the tube circumference perpendicularly to the inner surface. The Zeiss-Axio Vision program was used for picture processing and analysis, as well as for measuring corrosion depth of damages in tube material. 
Structural characterization of deposit was made using X-ray diffraction (XRD) technique. Structural analysis of powdered samples was performed by Siemens D-500 powder diffractometer. CuK $\alpha$ radiation was used in conjuction with a $\mathrm{CuK}_{\beta}$ nickel filter.

\section{Samples and preparation}

Economizer specimens were cut out by SiC abrasive disk cooling with water. Scraped deposit was sent to XRD analysis in order to determine its phase composition.

After submergence in the methacrylate, the specimens for microstructural examination were honed using SiC papers with fineness from 80 to 1000 and permanently cooling with water. Polishing was performed by diamond paste fineness of 10 to $5 \mu \mathrm{m}$ and $2-0 \mu \mathrm{m}$. Tube specimens were observed before and after chemical etching which was performed by $2 \%$ nitric acid $\left(\mathrm{HNO}_{3}\right)$ in ethanol.

\section{RESULTS AND DISCUSSION}

\section{Microstructure analysis}

Six specimens were analyzed and results indicated that their internal surfaces are covered by scaled, scabrous, bulging and rugged deposit layer which is brown/reddish color. Metal surface was caved, crannied and holey. A representative specimen is shown on Figure 1.

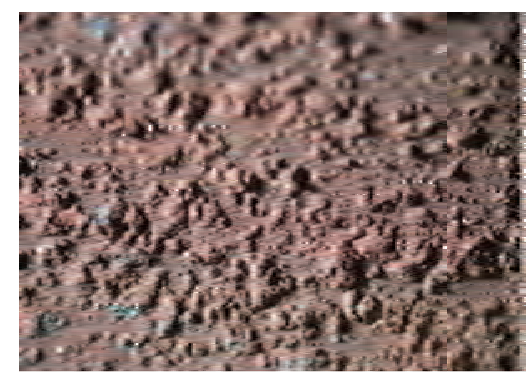

Figure 1. Internal surface of economizer.

The microstructures of wall tube cross section for all specimens are presented on Figure 2. Distinctive feature of economizer's microstructure is presence of longitudinal cracks, approximately $50 \mu \mathrm{m}$ length in material, which were propagated parallel to the tube surface (specimens 1 and 3). It pointed at the stress corrosion effect. Due to the presence of cracks in the tube wall further exposure to the same environment and strain will lead to the growth of cracks and rupture of tubes. Even very small concentrations of certain highly active chemicals, like chloride, have a huge contribution to the uprising the stress corrosion cracking and usually leading to devastating and unexpected failure. Corrosion pits (specimens 2, 4 and 6) that were rec-

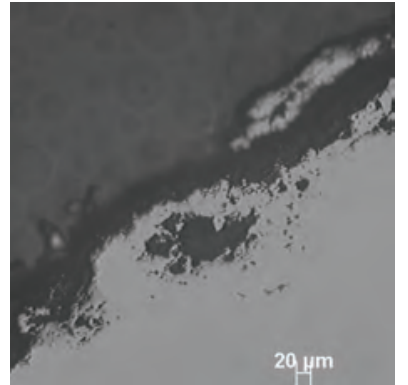

(a)

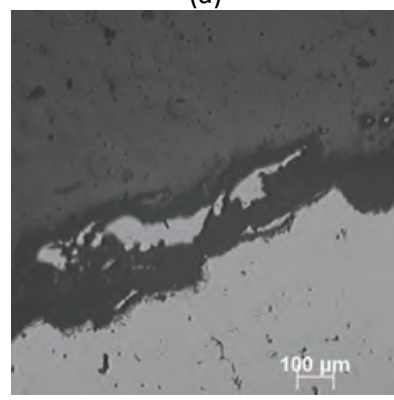

(c)

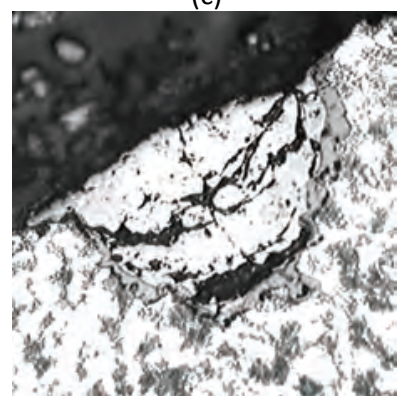

(e)

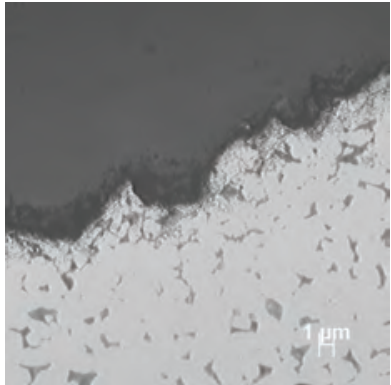

(b)

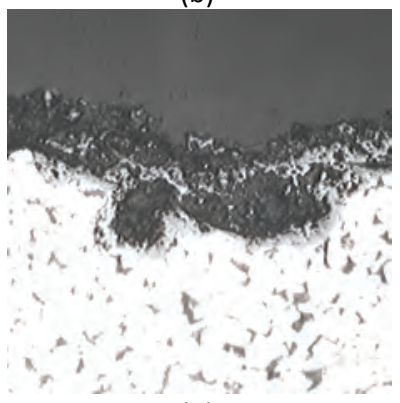

(d)

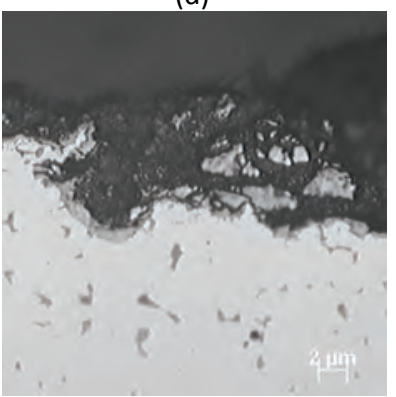

(f)
Figure 2. Cross-sectional view of specimens: a) specimen 1 with stress corrosion cracking, b) specimen 2 with corrosion pits, c) specimen 3 with stress corrosion, d) specimen 4 with corrosion pits, e) specimen 5 with cracks in oxide layer and f) specimen 6 with corrosion pits.

orded on microphotographs, clearly indicated that pitting corrosion took place in all specimens. Pitting corrosion could be attributed to the oxygen attack to the metal substrate. Microstructure analysis evinced destruction of the protective layer (specimen 5 ) that led to development of nonprotective scale localized on the internal tube surface. The precipitation of magnetite scale can increase the tube metal temperature and cause cracks and other deformations of metal construction [14-16]. Thickness of deposit layer varied between 13 and $160 \mu \mathrm{m}$. Whereas analysis revealed excess of chloride in feedwater, one of possible explanations of developing nonprotective magnetite can be based on the mechanism of local formation of acid chlorides. Result of this process is $\mathrm{pH}$ drop, due to creating an acidic region with a high $\mathrm{Cl}^{-}$concentration. Hydrolysable chlorides cause degradation in these zones of the protective film. The most likely cause of increased concentration of chloride in feedwater is hydrochloric acid $(\mathrm{HCl})$ 
utilized for regeneration of the ion exchange resins in condensate polisher. Consequently, the chloride concentration can be diminished by proper regeneration of polishing and water treatment plants and their accurate exploitation. Introducing of continuous on-line and daily laboratory monitoring of chloride in demi and feedwater by ion chromatography technique are also important measures for maintaining chloride below specified target values. Aside from that, the attention should be paid to the control and cease of condenser leakage that can be an additional source of chloride in feedwater. On the basis of obtain microphotographs, material microstructure was unmodified and consisted of ferrites and perlites.

\section{Structural and elemental characterization of the deposit}

Structural characterization of deposit was made using X-ray diffraction (XRD). The main constituents of deposit from specimens $1,2,3,4,5$ and 6 have confirmed to be magnetite $\left(\mathrm{Fe}_{3} \mathrm{O}_{4}\right)$ and hematite $\left(\mathrm{Fe}_{2} \mathrm{O}_{3}\right)$ (Figure 3). The deposit layer composition of specimens 5 and 6 consists of magnetite and prevalent amount of hematite. Iron oxides are typical steel oxidation products $(9,14,17-19)$. However, the presence of hematite may indicate irregularity in the power cycle operation and high corrosion rate. Moreover, hematite does not provide corrosion protection and has lower electrical and thermal conductivity than magnetite. Hematite also might be carried over to the boiler tubes from other part of the system. Though magnetite is protec- tive corrosion product, in present case its porous and brittle nature might have an adverse effect on the protection of the boiler tube surface. Porous magnetite rust can enhance the corrosion at the tube surface by acting as an active cathodic site and deploy underdeposited corrosion [20].

The three representative specimens (3, 4 and 5) were considered for the EDS analysis of deposit. Deposit seated inside the cavities and craters was undergone analysis. Results for specimen 3 indicated iron-oxide forming elements (Fe 69.15-70.42\% and 0 27.15$-29.36 \%$ ) as main components of rust. Other peaks corresponding to $\mathrm{Si}, \mathrm{Cu}, \mathrm{S}, \mathrm{Cr}, \mathrm{Mn}, \mathrm{Co}$ and $\mathrm{Ni}$ were registered with very low intensity. Depth of crater was 130 $\mu \mathrm{m}$. Deposit of specimen 4 originated from crater depth of $100 \mu \mathrm{m}$. Deposit contained O (27.52-31.38\%) and $\mathrm{Fe}$ (34.91-72.53\%). Elements presented in low portions were $\mathrm{Na}, \mathrm{Cl}, \mathrm{Mg}, \mathrm{Cr}, \mathrm{Zn}, \mathrm{K}$ and $\mathrm{Co}$, although $\mathrm{Si}$ was present at the mass fraction of $19.27 \%$. On specimen 5 the uppermost elements found within crater deep 220 $\mu \mathrm{m}$ were $\mathrm{Fe}(64.19 \%)$ and $\mathrm{O}(28.81 \%)$. Elements presented at minor levels were $\mathrm{Si}, \mathrm{Cu}, \mathrm{S}, \mathrm{Mg}, \mathrm{Cr}, \mathrm{Co}, \mathrm{Zn}$ and As. The $\mathrm{Cu}$ was present to the extent of $1.16 \%$. The presence of copper found in the brown/reddish depositlayer, can enforce the localized corrosion of boiler tubes through galvanic corrosion [21]. The source of copper is corrosion and decomposition of condenser tubes expressly in presence of excessive ammonia in the boiler feedwater [21-24].

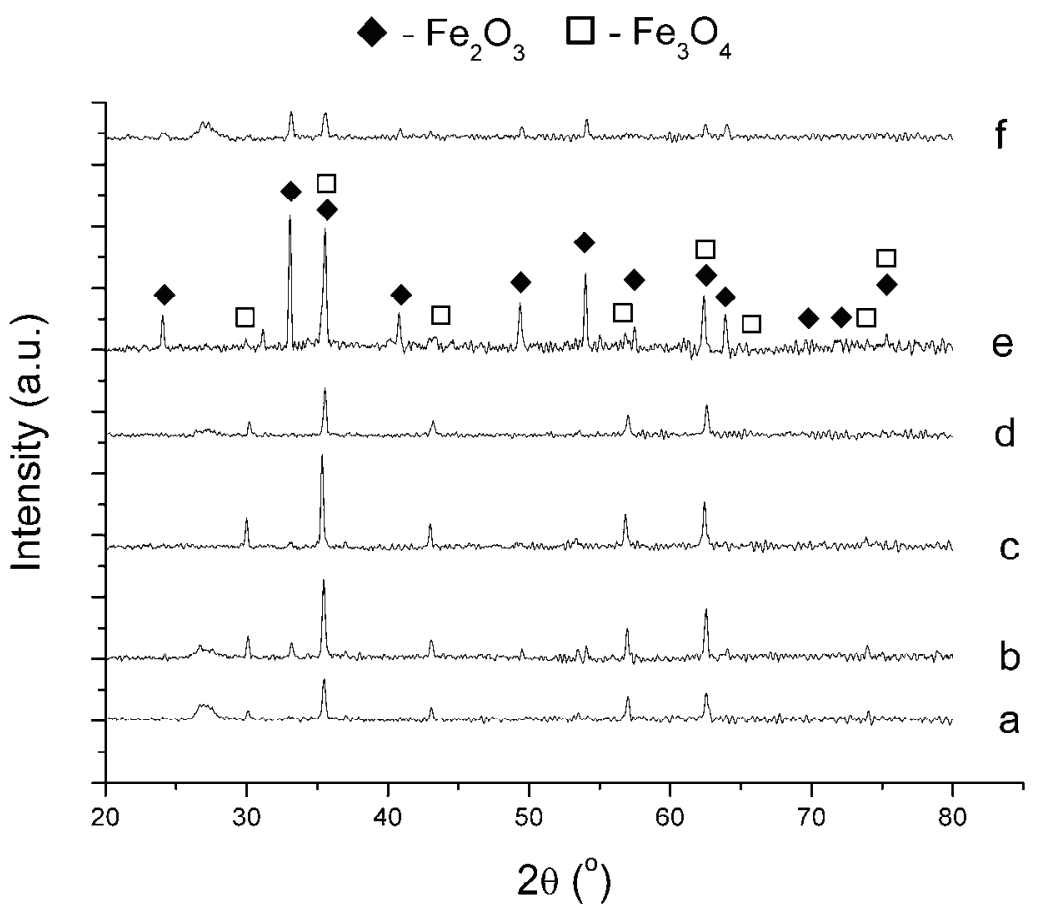

Figure 3. Difractogram of specimens: a) 1, b) 2, c) 3, d) 4, e) 5 and f) 6 . 


\section{CONCLUSION}

Obtained results of microstructure analysis of the boiler tubes lead to the conclusion that impurities present in feedwater resulted in corrosion pits, stress corrosion cracking, as well as destruction of protective magnetite layer. The protective magnetite layer lost its protective function which was followed by magnetite scale formation that can increase the tube metal temperature at these localized sites. Magnetite is commonly protective corrosion product but, in present case, its porous and brittle feature might have an adverse effect on tube surface protection. Structural characterization of the deposit proved that it was composed mainly of magnetite and hematite. SEM/EDS have shown that impurities associated with pits and cracking included $\mathrm{Fe}, \mathrm{O}, \mathrm{Cl}, \mathrm{Cu}, \mathrm{Na}$ and Si. Regular and correct monitoring of corrosive contaminants in water/ /steam cycle is crucial for prevention of corrosion processes and minimizing deposit formation on water-wall boiler tubes. Consequently, proper water chemistry is paramount in extending the life and increasing reliability of the unit.

\section{Acknowledgments}

This research was supported by the Ministry of Education, Science and Technological Development of the Republic of Serbia (Projects Nos. III 43009 and III 45012).

\section{REFERENCES}

[1] State-of-Knowledge on deposition, Part I: Parameters Influencing Deposition in Fossil Boilers, TR-1004194, Palo Alto, CA, 2002.

[2] O. Jonas, Monitoring of Steam plants, Mater. Performance 42 (2003) 38-42.

[3] R.J. Niebo, Implementing a Boiler Tube Failure Mechanism Reporting Program, in Proceeding of International Conference on Boiler Tube Failures in Fossil Plants, TR100493, Electric Power Research Institute, Palo Alto, CA, 1992.

[4] J.P. Dimmer, R.B. Dooley, EPRI's New BTF Reduction Program, in Proceedings of Third International Conference on Boiler Tube Failures in Fossil Plants, TR-107775, Electric Power Research Institute, Palo Alto, CA, 1998.

[5] E. Thurston, Inspecting for Corrosion Fatigue, Power Eng. 112 (2008) 46-49.
[6] R.B. Dooley, W.P. McNaughton, Don't let those Boiler Tubes Fail Again, Power Eng. 101 (1997) 56-61.

[7] Cost of Corrosion in the Electric Power Industry (EPRI Report TR-1004662), Palo Alto, CA, 2001.

[8] B.C. Syrett, J.A. Gorman, Cost of Corrosion in the Electric Power Industry - An Update, Mater. Performance $\mathbf{4 2}$ (2003) 32-38.

[9] A. Husain, K. Habib, Investigation of tubing failure of super-heater boiler from Kuwait Desalination Electrical Power Plant, Desalination 183 (2005) 203-208.

[10] D. Flynn, The Nalco Water Handbook, $3^{\text {rd }}$ Ed., McGrawHill, New York, 2009.

[11] A. Henderson, D. Brazil, Failure analysis of HP feedwater line elbow, Power Plant Chemistry 14 (2012) 76-82.

[12] E. Ring, Start-up, Shut-down and Lay-up Improvements at Earing Power Station, Power Plant Chemistry 14 (2012) 489-507.

[13] M.R. Mozdianfard, E. Behranvand, A field study of fouling in CDU preheaters at Esfahan refinery, Appl. Therm. Eng. 50 (2013) 908-917.

[14] W.E. Bornak, Chemistry of iron and its corrosion products in boiler system, Corrosion 44 (1988) 153-158.

[15] F.R. Hitchings, P.M. Unterweiser, Eds., On-Load Corrosion in Tubes of High-Pressure Boilers, ASM International, Materials Park, OH, 1981.

[16] Steam: Its Generation and Use, $38^{\text {th }}$ ed., Babcock and Wilcox, New York, 1972.

[17] Yu.V. Zenkevic, V.E. Sekretar, Formation of Iron Oxide Deposits in Supercritical Steam Generator, Therm. Eng. 11 (1976) 66-69.

[18] N.N. Mankina, A.G. Tkachenko, L.G. Buinovskaya, Methods of Determination of Iron Oxide Deposition on Inner Heat Exchange Surfaces of High-Pressure Boilers, Therm. Eng. 9 (1960) 30-34.

[19] H.M. Shalaby, On the Mechanism of Formation of Hot Spots in Boiler Tubes, Corrosion 62 (2006) 930-941.

[20] M.G. Fontana, Corrosion Engineering, McGraw-Hill Book Company, 1986.

[21] F.N. Kemmer, ed., The NALCO Water Handbook, $2^{\text {nd }}$ Ed., McGraw-Hill, New York, 1988.

[22] Copper Alloy Corrosion in High Purity Feedwater, Electric Power Research Institute, TR-1000456, Palo Alto, CA, 2000.

[23] Corrosion of $\mathrm{Cu}-\mathrm{Ni}-\mathrm{Zn}$ Alloys in Water-Ammonia Power Plant Environments, Electric Power Research Institute, TR-113697, Palo Alto, CA, 1999.

[24] State-of-Knowledge of Copper in Fossil Plant Cycles, Electric power research Institute, TR-108460, Palo Alto, CA, 1997. 


\section{IZVOD}

\section{OŠTEĆENJA UNUTRAŠNJEG ZIDA EKONOMAJZERA IZAZVANA NEČISTOĆAMA U NAPOJNOJ VODI}

Sonja M. Vidojković ${ }^{1}$, Antonije E. Onjia ${ }^{2}$, Aleksandar B. Devečerski ${ }^{3}$, Nebojsa N. Grahovac ${ }^{3}$, Aleksandra B. Nastasović ${ }^{1}$

${ }^{1}$ Univerzitet u Beogradu, Institut za hemiju, tehnolgiju i metalurgiju, Beograd, Srbija

${ }^{2}$ Univerzitet u Beogradu, Laboratorija za hemijsku dinamiku i permanentno obrazovanje, Institut za nuklearne nauke "Vinča", Beograd, Srbija

${ }^{3}$ Univerzitet u Beogradu, Laboratorija za materijale, Institut za nuklearne nauke "Vinča", Beograd, Srbija

(Stručni rad)

Osnovni uzroci smanjenja efikasnosti na termoelektranama su oštećenja i pucanja kotlovskih cevi koja utiču na smanjenje pouzdanosti i raspoloživosti termoblokova što dovodi do povećanja cene električne energije. Cevi se najčešće izrađuju od ugljeničnog ili niskolegiranog čelika i izložene su naprezanju, agresivnom okruženju i dejstvu različitih faza vode na visokim tempeaturama i pritiscima. Jedan od razloga pucanja cevi i oštećenja konstrukcionog materijala je prisustvo nečistoća u napojnoj vodi koje se akumuliraju ispod naslaga i dovode do razvoja korozionih procesa. Zbog toga, redovno ispitivanje kotlovskih cevi predstavlja neophodnu meru u cilju prevencije zastoja termoblokova. Na termoelektrani dokritičnih parametara snage 210 MW zabeležen je porast zastoja izazvanih oštećenjima cevnog sistema koja su u najvećem broju slučajeva bila na ekonomajzeru. Ispitivani kotao je sa prirodnom cirkulacijom, radi na ugalj, a konstrukcioni material je čelik St.45.8 prema DIN 17175. Da bi se utvrdilo stanje unutrašnjeg zida ekonomajzera i otkrili mogući uzroci oštećenja izvršena su metalografska ispitivanja njegovog unutrašnjeg zida kao i sastava naslaga. Analize su obuhvatale ispitivanje mikrostrukture, analizu hemijskog sastava naslaga pomoću rendgenske difrakcije (XRD) i skenirajuće mikroskopske elektronske analize/energetske disperzione spektroskopije (SEM/EDS). Prsline zbog naponske korozije, tačkasta korozija, razoren zaštitni sloj magnetita, prisustvo hematita u naslagama i korozione nečistoće nađene u pukotinama cevi ukazale su na dejstvo neadekvatnog kvaliteta napojne vode koja ne obezbeđuje pouzdan rad kotla. Magnetit, koji inače ima zaštitnu funkciju, dobio je poroznu strukturu i postao krt i lomljiv, što može imati štetne efekte na cevi kotla. Strukturna karakterizacija naslaga pokazala je da se one sastoje uglavnom od magnetita i hematita, a na osnovu SEM/EDS analiza zaključeno je da se u prslinama nalaze $\mathrm{Fe}, \mathrm{O}, \mathrm{Cl}, \mathrm{Cu}, \mathrm{Na}$ i Si. U cilju prevencije korozije i naslaga na kotlovskim cevima predloženo je uvođenje adekvatnog monitoringa korozionih nečistoća u vodeno/parnom ciklusu. Regularna hemijska kontrola vode je od izuzetnog značaja za produženje radnog veka postojenja i povećanje pouzdanosti termobloka.
Ključne reči: Kotlovske cevi • Naslage • Korozija $\bullet$ Kontaminanti u napojnoj vodi 